\title{
STD-Dependent and Independent Encoding of Input Irregularity as Spike Rate in a Computational Model of a Cerebellar Nucleus Neuron
}

\author{
Johannes Luthman • Freek E. Hoebeek • \\ Reinoud Maex • Neil Davey • Rod Adams • \\ Chris I. De Zeeuw • Volker Steuber
}

Published online: 15 July 2011

(C) The Author(s) 2011. This article is published with open access at Springerlink.com

\begin{abstract}
Neurons in the cerebellar nuclei $(\mathrm{CN})$ receive inhibitory inputs from Purkinje cells in the cerebellar cortex and provide the major output from the cerebellum, but their computational function is not well understood. It has recently been shown that the spike activity of Purkinje cells is more regular than previously assumed and that this regularity can affect motor behaviour. We use a conductance-based model of a $\mathrm{CN}$ neuron to study the effect of the regularity of Purkinje cell spiking on $\mathrm{CN}$ neuron activity. We find that increasing the irregularity of Purkinje cell activity accelerates the $\mathrm{CN}$ neuron spike rate and that the mechanism of this recoding of input irregularity as output spike rate depends on the number of Purkinje cells converging onto a $\mathrm{CN}$ neuron. For high convergence ratios, the irregularity induced spike rate acceleration
\end{abstract}

Electronic supplementary material The online version of this article (doi:10.1007/s12311-011-0295-9) contains supplementary material, which is available to authorized users.

J. Luthman $\cdot$ R. Maex $\cdot$ N. Davey $\cdot$ R. Adams $\cdot$ V. Steuber $(\bowtie)$

Science and Technology Research Institute, University

of Hertfordshire,

College Lane,

Hatfield AL10 9AB, UK

e-mail: v.steuber@herts.ac.uk

F. E. Hoebeek • C. I. De Zeeuw

Department of Neuroscience, Erasmus MC,

Dr Molewaterplein 40,

3015 GD Rotterdam, The Netherlands

C. I. De Zeeuw

Netherlands Institute for Neuroscience, Royal Academy of Arts

\& Sciences (KNAW),

Meibergdreef 47,

1105 BA Amsterdam, The Netherlands depends on short-term depression (STD) at the Purkinje cell synapses. At low convergence ratios, or for synchronised Purkinje cell input, the firing rate increase is independent of STD. The transformation of input irregularity into output spike rate occurs in response to artificial input spike trains as well as to spike trains recorded from Purkinje cells in tottering mice, which show highly irregular spiking patterns. Our results suggest that STD may contribute to the accelerated $\mathrm{CN}$ spike rate in tottering mice and they raise the possibility that the deficits in motor control in these mutants partly result as a pathological consequence of this natural form of plasticity.

Keywords Cerebellar nuclei · Purkinje cell $\cdot$ Short-term depression $\cdot$ Tottering $\cdot$ Ataxia

\section{Introduction}

The cerebellar nuclei $(\mathrm{CN})$ form the main gateway out of the cerebellum. Neurons in the $\mathrm{CN}$ integrate their intrinsic activity with potent inhibitory inputs from Purkinje cells in the cerebellar cortex and with excitatory inputs from mossy fibre and climbing fibre collaterals. Although $\mathrm{CN}$ neurons are placed to play a central role for cerebellar computation, their contribution to information processing and neural coding remains poorly understood.

The $\mathrm{CN}$ are composed of several types of neurons, including inhibitory projection neurons that project to the inferior olive and excitatory projection neurons that project to the thalamus and red nucleus [1-8]. Both neuron types are intrinsically active and fire rebound spike bursts at the offset of hyperpolarising current injections and after inhibitory synaptic input trains [6, 9-12], opening up the 
possibility for bidirectional rate modulation by synaptic input. Each $\mathrm{CN}$ neuron receives inhibitory input from a number of cerebellar cortical Purkinje cells via somatic and dendritic gamma aminobutyric acid $(\mathrm{GABA})_{\mathrm{A}}$ receptors. Little information is available about the exact number of Purkinje cells converging onto a single $\mathrm{CN}$ neuron; the estimates range between 100 (CIDZ, unpublished data; [13, 14]) and 860 [15]. A characteristic feature of the inhibitory synapses between Purkinje cells and $\mathrm{CN}$ neurons is that they exhibit short-term depression (STD) [16, 17], implying that the effect of a Purkinje cell spike on the $\mathrm{CN}$ neuron response depends on preceding Purkinje cell spiking. The functional role of STD at the Purkinje cell onto CN neuron synapse remains to be elucidated.

The modulation of $\mathrm{CN}$ neuron output by inhibitory input from Purkinje cells is expected to depend on two other features of the Purkinje cell activity. Firstly, a total or partial synchronisation of spike trains from Purkinje cells projecting onto the same $\mathrm{CN}$ neuron will affect the $\mathrm{CN}$ neuron response by effectively lowering the functional convergence ratio. Secondly, the degree of irregularity of the Purkinje cell spike trains should influence the $\mathrm{CN}$ neuron output [18]. Recent recordings from Purkinje cells in vivo have shown that their spike trains are more regular than previously assumed, with short periods of regular firing that are interspersed with pauses [19]. Interestingly, the extent of these regular periods can be affected by sensory stimulation [19]. Moreover, the irregularity of Purkinje cell spiking can be increased by pathologies; a mutation in the Cacnala gene, which encodes the pore-forming $\alpha_{1 \mathrm{~A}}$-subunit of P/Qtype voltage-gated calcium channels, induces irregular Purkinje cell firing in tottering mice $[20,21]$. Although the amplitude of modulation of the Purkinje cell firing rate during optokinetic stimulation is unchanged in tottering mice, these natural mutants show pronounced ataxia [2022]. Moreover, the use of regular stimulation patterns [20] and pharmacological activation of calcium-activated potassium channels [21] rescues the ataxic motor behaviour, which together underline the causal link of irregular Purkinje cell firing with aberrant cerebellar information processing. The importance of irregular neuronal activity and noisy inputs for the computational capabilities of neurons has been the subject of previous theoretical studies (for review, see [23]).

In this study, we examine the integrated effects of regular versus irregular Purkinje cell activity, STD at the Purkinje cell onto $\mathrm{CN}$ neuron synapse and varying convergence ratios of Purkinje cells per $\mathrm{CN}$ neuron. We use computer simulations of a data-driven conductance-based model of an excitatory projection neuron in the $\mathrm{CN}$ [24] and we investigate its responses to artificially generated spike trains with different degrees of regularity and to spike trains from Purkinje cells in tottering and wild-type mice.

\section{Materials and Methods}

The simulations were performed with the NEURON simulation software [25]. Analyses were conducted using MATLAB r2008b (The Mathworks). Data are given as mean \pm standard deviation.

\section{CN Neuron Model}

All simulations used a multi-compartmental conductancebased model of an excitatory CN projection neuron [24]. The model, originally implemented in GENESIS [26], was translated to NEURON to simplify the modelling of STD. Figure 1a shows the morphology of the $\mathrm{CN}$ neuron model and the sources of its synaptic inputs. Briefly, the model comprised 517 compartments and eight ion channels that were represented using Hodgkin-Huxley type models: a fast sodium current, a mixture of fast $\mathrm{Kv} 3$ and slow $\mathrm{Kv} 2$ delayed rectifiers, which together form a TEA-sensitive Kdr current, a tonic non-specific cation current providing inward current to allow baseline spiking, a high voltageactivated (HVA) calcium current, a purely calcium-gated potassium (Sk) current, a hyperpolarization-activated cyclicnucleotide gated $(\mathrm{HCN})$ current, a Cav3.1 low-voltage activated (LVA) calcium current and a persistent sodium $(\mathrm{NaP})$ current. The intracellular calcium concentration was modelled as a submembrane shell with calcium inflow from the HVA current and an exponential decay with a time constant of $70 \mathrm{~ms}$. To replicate in vivo conditons, the simulation temperature was set to $37^{\circ} \mathrm{C}$. The temperature correction was performed using a $\mathrm{Q}_{10}$ of 3 for the activation and inactivation time constants of the voltage-gated channels [27] and a $Q_{10}$ of 1.4 for the channel conductances [27]. In the absence of any synaptic input, the model showed regular spiking at a spontaneous rate of $26 \mathrm{~Hz}$ (Fig. 1c, top trace).

\section{Synaptic Input}

The model received excitatory input from 150 mossy fibre synapses, 100 of which were added to 100 randomly chosen dendritic compartments, with the remaining 50 synapses situated in the soma. Inhibitory input was provided by 450 Purkinje cell synapses, one for each of 400 randomly chosen dendritic compartments and 50 placed on the soma. Synapses were modelled as bi-exponential postsynaptic conductance changes with rise and decay time constants as described in [24], adjusted to $37^{\circ} \mathrm{C}$ by using a $\mathrm{Q}_{10}$ of $2[28,29]$. The conductances of the excitatory synapses were set to the high synaptic gain values in [24]; temperature correction to $37^{\circ} \mathrm{C}$ with a $\mathrm{Q}_{10}$ of 1.4 [27] resulted in a peak value of $310 \mathrm{pS}$ for the 2-amino-3-(5-methyl-3-oxo-1,2-oxazol-4yl)propanoic acid (AMPA) conductance and peak values of 
a

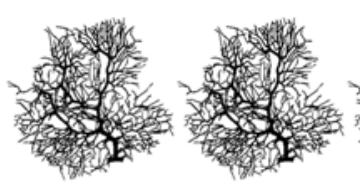

\section{1 - 450 Purkinje cells}

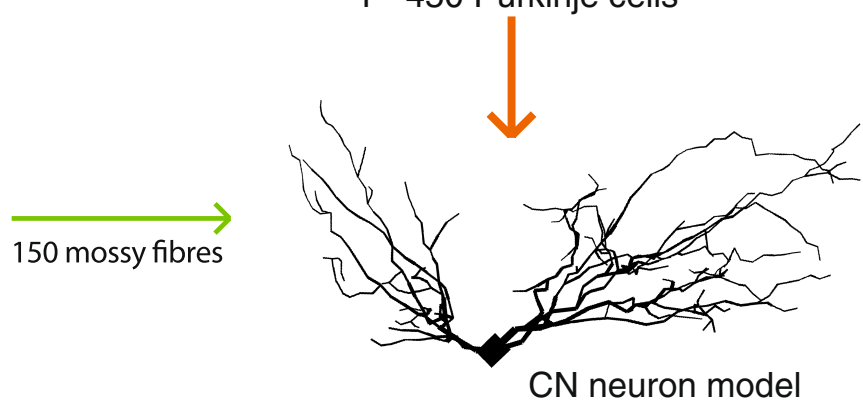

$\mathrm{CN}$ neuron model

C

CN neuron model

Without synaptic input

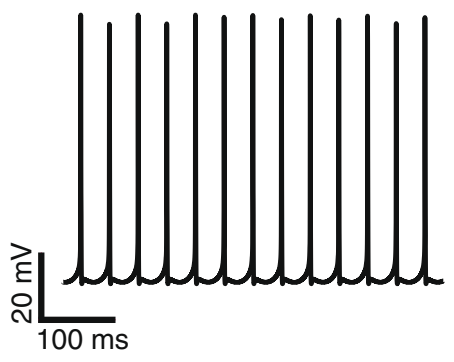

With tottering input

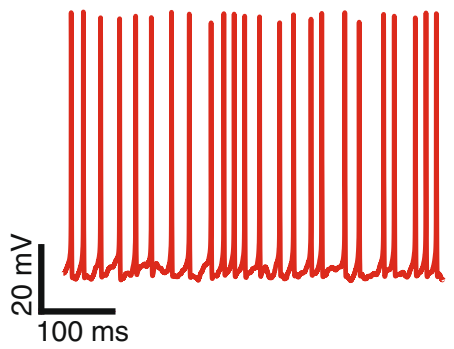

b

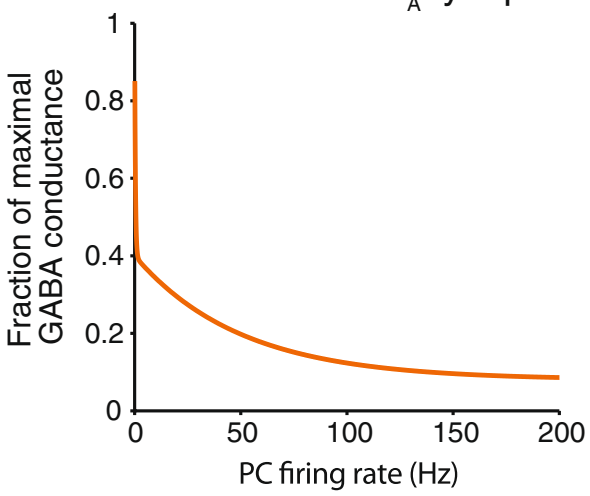

e Typical ISI distributions of PCs
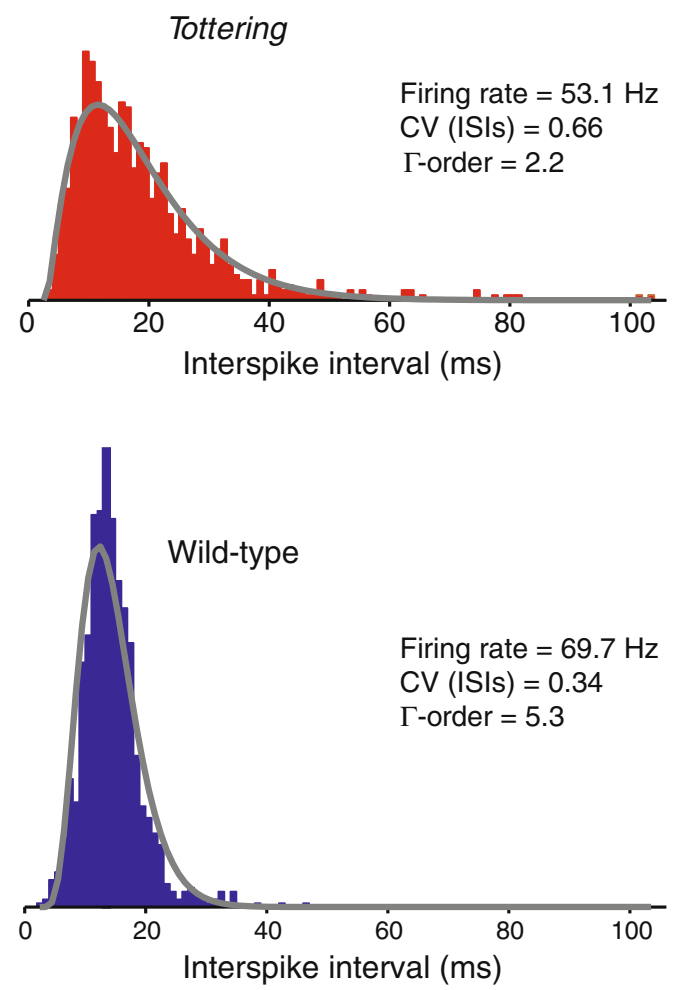

Fig. 1 Overview of the simulation setup. a The $\mathrm{CN}$ model received excitatory input from 150 mossy fibres, modelled as spike generators with a mean firing rate of $20 \mathrm{~Hz}$. Purkinje cell (PC) input to the $\mathrm{CN}$ model was provided by $1-450$ independently firing spike generators. In the study with Purkinje cell trains recorded from tottering and wild-type mice, the input comprised 1-150 individual trains. b Dependence of STD at the Purkinje cell to CN neuron synapse on Purkinje cell firing rate as modelled by [19]. c Membrane potential traces of the $\mathrm{CN}$ model.

177 and $88 \mathrm{pS}$ for the fast and slow components of the $\mathrm{N}$ methyl-D-aspartate (NMDA) conductance, respectively. These values remained constant during all simulations; the effect of plasticity at the mossy fibre synapses $[30,31]$
Top panel the model was tuned to fire at approximately $26 \mathrm{~Hz}$ in the absence of synaptic inputs. Bottom panel typical response to Purkinje cell spike trains from tottering mice (convergence ratio $150,+$ STD). d Spike raster plots showing $500 \mathrm{~ms}$ samples from each of the tottering $(n=37)$ and wild-type $(n=28)$ Purkinje cell recordings. e ISI distributions of two representative 15-s Purkinje cell trains used in the simulations. Grey curves are fits to gamma distribution functions (see "Materials and Methods" section)

was considered beyond the scope of the present study. STD of the Purkinje cell synapses was modelled as described by Shin et al. [19] (based on [17], Fig. 1b). In the presence of STD, the peak $\mathrm{GABA}_{\mathrm{A}}$ conductance at the 
Purkinje cell synapses was set to $1.89 \mathrm{nS}$ at $37^{\circ} \mathrm{C}$ (corresponding to $1.6 \mathrm{nS}$ at $32^{\circ} \mathrm{C}$ ). The nearly tenfold increase of the inhibitory synaptic conductance compared to the value in the original model [24], which was based on previous experimental data and dynamic clamp experiments $[32,33]$, reflects the higher conductance values that were reported more recently [34]. The reversal potentials of the excitatory and inhibitory synaptic currents were set to 0 and $-75 \mathrm{mV}$, respectively.

To be able to evaluate the contribution of STD at the inhibitory synapses to the encoding of inhibitory input irregularity as output spike rate, simulations with and without STD had to inject the same mean conductance into the $\mathrm{CN}$ neuron model when the input spike trains were completely regular (coefficient of variation $(\mathrm{CV})$ of inter-spike intervals (ISIs) $=0$ ). This was achieved by adjusting the peak conductance of input trains in simulations without STD according to the spike rate dependence of the conductance in the presence of STD as modelled by Shin et al. [19] (Fig. 1b). For example, spike trains at $62 \mathrm{~Hz}$ activated a constant peak conductance of $327 \mathrm{pS}$ in the absence of STD, which equalled the steady state value of the peak conductance resulting from regular input trains at the same rate with STD. Nondepressing spike trains at higher (lower) rates activated lower (higher) peak conductances (for example, $182 \mathrm{pS}$ at $150 \mathrm{~Hz}, 233 \mathrm{pS}$ at $100 \mathrm{~Hz}, 484 \mathrm{pS}$ at $30 \mathrm{~Hz}$ and $647 \mathrm{pS}$ at $10 \mathrm{~Hz}$; compare Fig. 1b).

\section{Generation of Artificial Purkinje Cell and Mossy Fibre} Spike Trains

In simulations using spike generators, the 450 inhibitory synapses of the $\mathrm{CN}$ neuron model were derived from one to 450 individual Purkinje cell inputs; usually up to 25 boutons originate from a single Purkinje cell axon [13]. These were generated with a custom made variant of NEURON's NetStim object (GammaStim). As with NetStim, the GammaStim generator allowed the setting of irregularity of spike trains from 0 (invariant ISIs corresponding to the specified mean rate) to 1 (ISIs drawn from a gamma distribution of chosen order, with the mean ISI corresponding to the specified mean rate), described by the equation:

ISI $=(1-x) y+x y z$

where, $x$ is the irregularity setting, $y$ is the desired mean ISI, and $z$ is a random number between 0 and 1 , drawn from a gamma distribution of specified order. The artificially generated Purkinje cell spike trains had variable irregularities and gamma orders (Fig. 2), while the artificial mossy fibre spike trains always exhibited a gamma order of 3 and an irregularity of 1 . Each of the 150 mossy fibre synapses received input from an independent spike generator, resulting in completely desynchronised mossy fibre input to the $\mathrm{CN}$ model.

\section{Quantifying Spike Train Regularity}

Recorded Purkinje cell spike trains and $\mathrm{CN}$ model outputs were characterised with descriptive statistics shown in Table 1. ISI distributions were fitted with gamma functions. The resulting gamma function order is given in column 4 of Table 1. Spike train microstructures were described by the $\mathrm{CV}_{2}$ [35], given by the equation:

$$
\mathrm{CV}_{2}=2 \frac{\left|\mathrm{ISI}_{n+1}-\mathrm{ISI}_{n}\right|}{\mathrm{ISI}_{n+1}+\mathrm{ISI}_{n}}
$$

The $\mathrm{CV}_{2}$ measurements are given in column 5 of Table 1 . $\mathrm{CV}_{2}$ data were also used to characterise periods of long regular spike patterns which are defined as parts of spike trains where four or more consecutive ISIs have a $\mathrm{CV}_{2} \leq 0.2$ [19]. The percentage of neuronal firing time in such patterns is given in the last column of Table 1.

\section{Electrophysiology and Biased Selection of Tottering and Wild-Type Trains}

For the simulations where real Purkinje cell spike trains were used, recordings were obtained from awake, headrestrained mice at rest. A total of 37 tottering and 28 wildtype Purkinje cells were recorded, comprising a total of approximately 5,000 and 4,000 s, respectively. These data and details of the recording methods were published before [20]. The raw spike trains were divided into 15-s long stretches, yielding 251 wild-type and 326 tottering trains. Of those, the tottering trains had a mean firing rate of $54.5 \pm$ $33.4 \mathrm{~Hz}$ while the wild-type trains had an average of $70.4 \pm$ 21.1 Hz. Figure 1d shows raster plots of stretches of tottering and wild-type spike trains and Fig. 1e shows representative ISI distributions.

Based on the finding that Purkinje cell axons are unable to faithfully transmit action potentials at more than $\sim 300 \mathrm{~Hz}$ [36], a spike-removal algorithm was applied that eliminated the second spike of each ISI that was shorter than $3 \mathrm{~ms}$. This procedure reduced the mean firing rates to $52.2 \pm$ 29.6 $\mathrm{Hz}$ for tottering vs. $70.1 \pm 21.0 \mathrm{~Hz}$ for wild type.

To keep mean firing rates constant, we used a biased selection mechanism; of the raw tottering trains, we used the trains with higher firing frequencies more often. Inversely, for the wild type, slower trains were used more frequently than faster ones. In total, 204 sets of each $150+$ 150 trains were created where the mean of a set was confined to the interval $61.3-62.3 \mathrm{~Hz}$. The groups were 
Fig. 2 STD dependent acceleration of $\mathrm{CN}$ neuron firing rate by increased input irregularity. a The firing rate of the $\mathrm{CN}$ neuron model in response to different degrees of irregularity in the inhibitory input spike trains in the presence $(+\mathrm{STD}$, black) and absence (-STD, grey) of synaptic depression at the Purkinje cell onto $\mathrm{CN}$ neuron synapse. $\mathbf{b}$ ISI distributions of the simulated input spike trains at irregularity settings of $0.4(I), 0.7(I I)$, and $1.0(I I I)$. The superposed curves are gamma function fits. The gamma orders for irregularities of 0.7 (II) and 1.0 (III) correspond to real Purkinje cell trains from wild-type and tottering mice, respectively

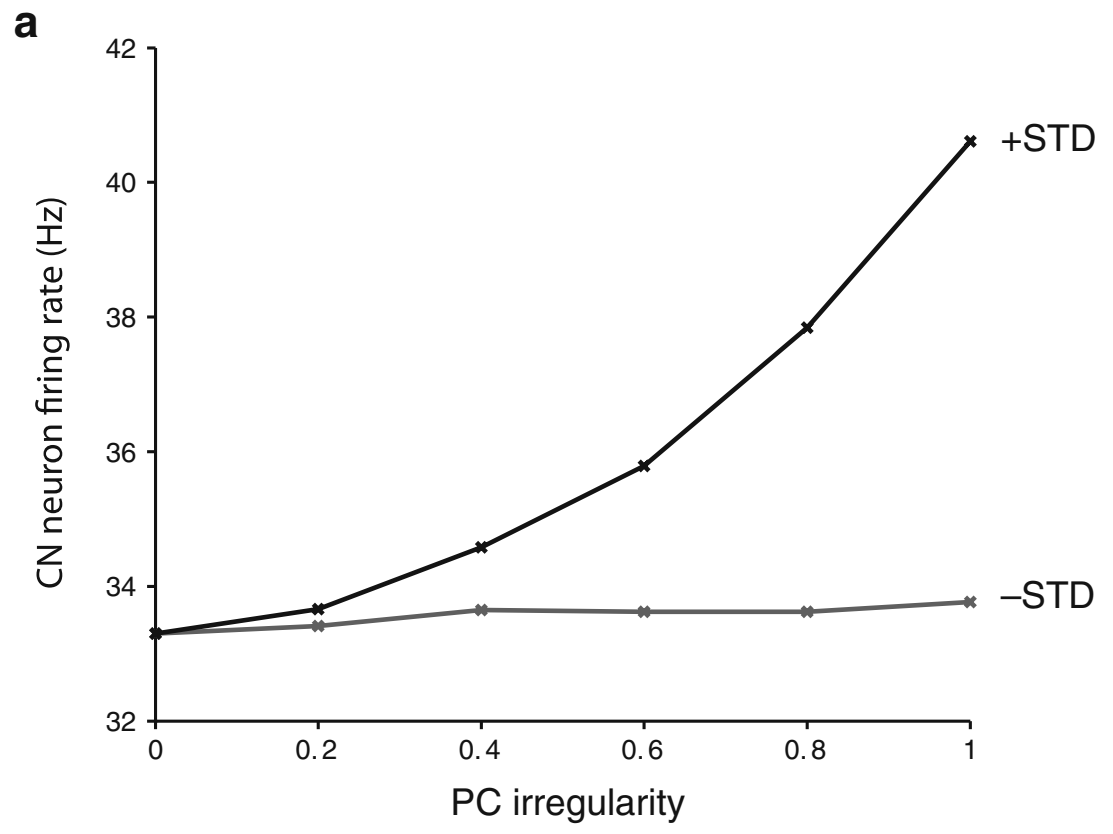

b

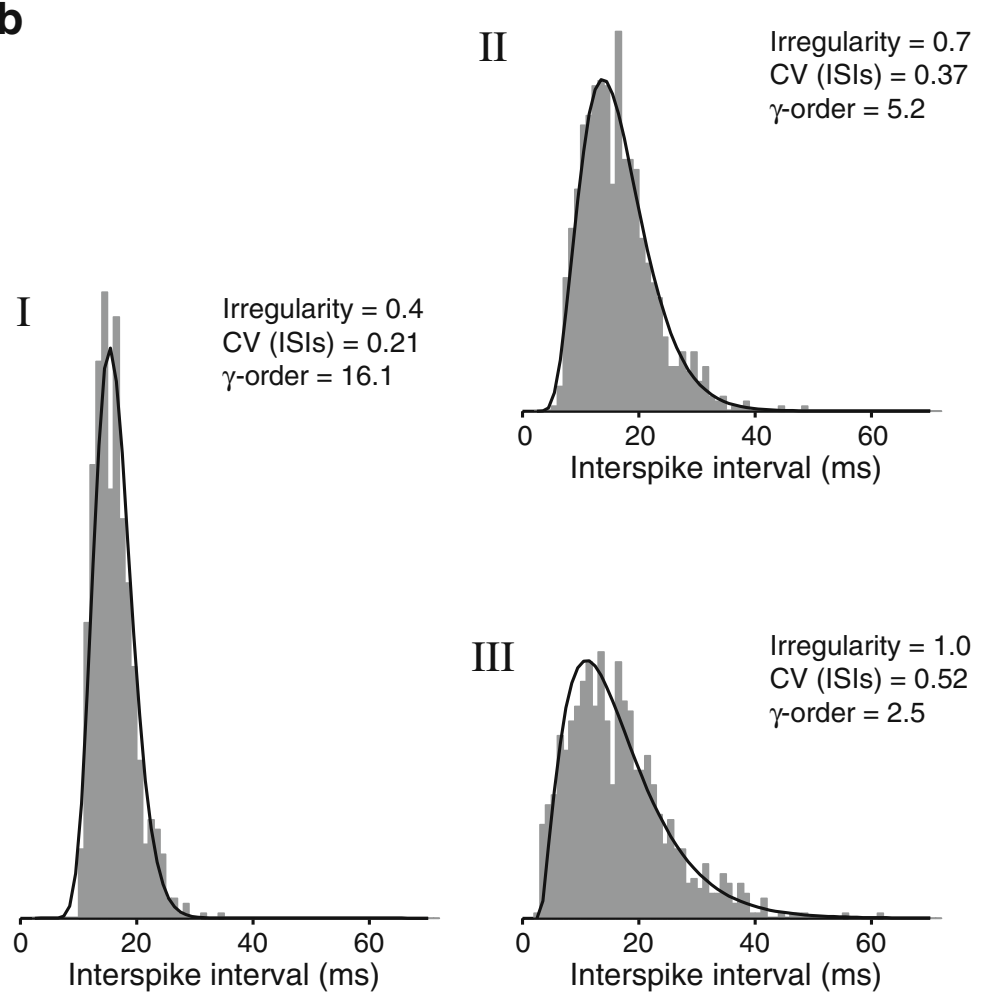

analysed using the same measures as for the pool of raw trains and revealed a good consistency of parameters prevs. post-selection (Table 1). Providing the model with inhibitory input from tottering Purkinje cell spike trains at a rate of $62 \mathrm{~Hz}$ and excitatory mossy fibre input at $20 \mathrm{~Hz}$ resulted in irregular $\mathrm{CN}$ neuron spiking at a rate of $48 \mathrm{~Hz}$ (for a convergence ratio of 150 Purkinje cells per $\mathrm{CN}$ neuron and in the presence of STD, Fig. 1c bottom).

\section{Results}

STD-Dependent Recoding of Input Irregularity as Output Firing Rate

It has recently been observed that Purkinje cells fire more regularly than previously assumed [19]. The central question that is addressed in this article is how the degree 
Table 1 Statistics of spike trains from tottering and wild-type Purkinje cells before and after selection

\begin{tabular}{|c|c|c|c|c|c|}
\hline & Firing rate & CV of ISIs & Gamma order & $\mathrm{CV}_{2}$ of ISIs & Percent of time in long patterns \\
\hline \multicolumn{6}{|c|}{ Raw Purkinje cell spike trains } \\
\hline Wild type $(n=251)$ & 70.1 & 0.45 & 4.56 & 0.39 & 18.4 \\
\hline $\mathrm{SD}$ & 21.0 & 0.16 & 2.40 & 0.10 & 12.5 \\
\hline Tottering $(n=326)$ & 52.2 & 1.72 & 2.23 & 0.56 & 7.8 \\
\hline SD & 29.6 & 1.28 & 1.57 & 0.18 & 9.6 \\
\hline \multicolumn{6}{|c|}{ After selection: per-set means } \\
\hline Wild type $(n=204 \times 150)$ & 61.8 & 0.46 & 4.87 & 0.38 & 20.0 \\
\hline Min & 61.3 & 0.44 & 4.59 & 0.37 & 18.5 \\
\hline Max & 62.3 & 0.47 & 5.13 & 0.39 & 21.5 \\
\hline Tottering $(n=204 \times 150)$ & 61.8 & 1.70 & 2.18 & 0.53 & 8.3 \\
\hline Min & 61.3 & 1.52 & 1.98 & 0.50 & 6.6 \\
\hline $\operatorname{Max}$ & 62.3 & 1.91 & 2.42 & 0.55 & 10.0 \\
\hline
\end{tabular}

of irregularity in Purkinje cell simple spike firing affects the output of the postsynaptic target neurons of the Purkinje cells in the CN. Figure 2 shows the effect of input irregularity on $\mathrm{CN}$ neuron output firing rate both in the presence and absence of STD at the Purkinje cell to $\mathrm{CN}$ neuron synapse. In these simulations, the $\mathrm{CN}$ neuron model was presented with artificially generated inhibitory input spike trains, which fired at the same mean rate of $60 \mathrm{~Hz}$ but exhibited varying degrees of irregularity (ranging from 0 to 1 , corresponding to a $\mathrm{CV}$ of ISI distributions between 0 and 0.5 , see "Materials and Methods" section). The number of Purkinje cells converging onto the $\mathrm{CN}$ neuron was initially set to 90 ; but given the uncertainty about real convergence ratios in vivo, this parameter was varied in all experiments below.

For a convergence ratio of 90 , increasing the irregularity of the input trains resulted in an increased $\mathrm{CN}$ neuron firing rate, but only if the inhibitory synapses exhibited STD. In the absence of STD, the irregularity dependent increase in firing rate disappeared (Fig. 2). Thus, a possible computational role for STD at the synapses between Purkinje cells and $\mathrm{CN}$ neurons is the recoding of input irregularity as output firing rate.

Response of the CN Neuron Model to Irregular Purkinje Cell Spike Trains from Tottering Mice and Effect of Different Convergence Ratios

An increased degree of irregularity in Purkinje cell spike activities has been found in tottering mice, which show impaired eye movements and motor control deficits [20, 21]. Moreover, it has recently been shown that $\mathrm{CN}$ neurons in anesthetised tottering mice exhibit enhanced spike rates compared to their wild-type littermates [37]. This suggests that the STD-dependent encoding of Purkinje cell irregularity as $\mathrm{CN}$ neuron spike rate that we found in our simulations might affect information processing and behaviour. We therefore presented the $\mathrm{CN}$ neuron model with Purkinje cell spike trains from tottering and wild-type mice. We obtained recordings of spontaneous simple spike activity in 37 tottering and 28 wild-type Purkinje cells from awake mice. As the tottering Purkinje cell spike trains in our recordings had a slightly lower mean rate than the wild-type ones (52.2 vs. $70.1 \mathrm{~Hz}$, respectively), we applied a selection procedure to generate subsets of tottering and wild-type trains of $15 \mathrm{~s}$ each with the same mean rate of $62 \mathrm{~Hz}$ (Fig. 3, see "Materials and Methods" section).

Figure $4 \mathrm{a}$ shows the spike rates of the $\mathrm{CN}$ model in response to tottering and wild-type Purkinje cell spike trains for different convergence ratios in the presence and absence of STD. For a number of 150 Purkinje cells converging onto the $\mathrm{CN}$ neuron, the responses of the $\mathrm{CN}$ neuron model to tottering and wild-type spike trains confirmed our results for artificially generated input trains (at a convergence of 90, Fig. 2). In the presence of STD at the Purkinje cell to $\mathrm{CN}$ neuron synapses, the $\mathrm{CN}$ neuron model responded with a $27.4 \%$ higher firing rate to the irregular spike trains from tottering Purkinje cells than to the more regular trains from wild-type cells (48.8 \pm 0.6 vs. $38.3 \pm 0.2 \mathrm{~Hz}, n=204)$. In the absence of STD, the difference in $\mathrm{CN}$ neuron firing rate in response to tottering and wild-type Purkinje cells was reduced to $2.4 \%$ (34.0 \pm 0.5 vs. $33.2 \pm 0.4 \mathrm{~Hz}, n=204)$. This suggests that STD at the synapses between Purkinje cells and $\mathrm{CN}$ neurons can contribute to the faster spiking in $\mathrm{CN}$ neurons from tottering mice with irregular Purkinje cell activity, which implies that STD is involved in the motor performance deficits in these mutants.

We also studied the response of the $\mathrm{CN}$ neuron model to tottering and wild-type Purkinje cell spike trains for lower convergence ratios, down to one Purkinje cell per $\mathrm{CN}$ neuron. Such low convergence ratios are unlikely to occur 


\section{a}

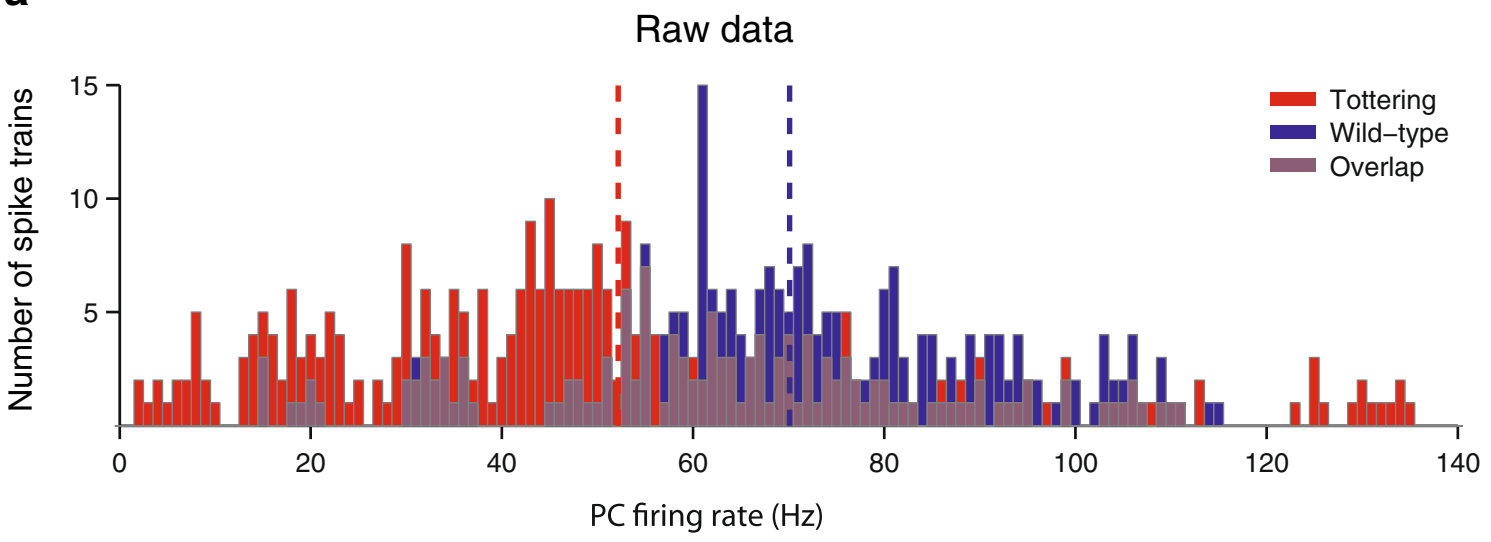

b

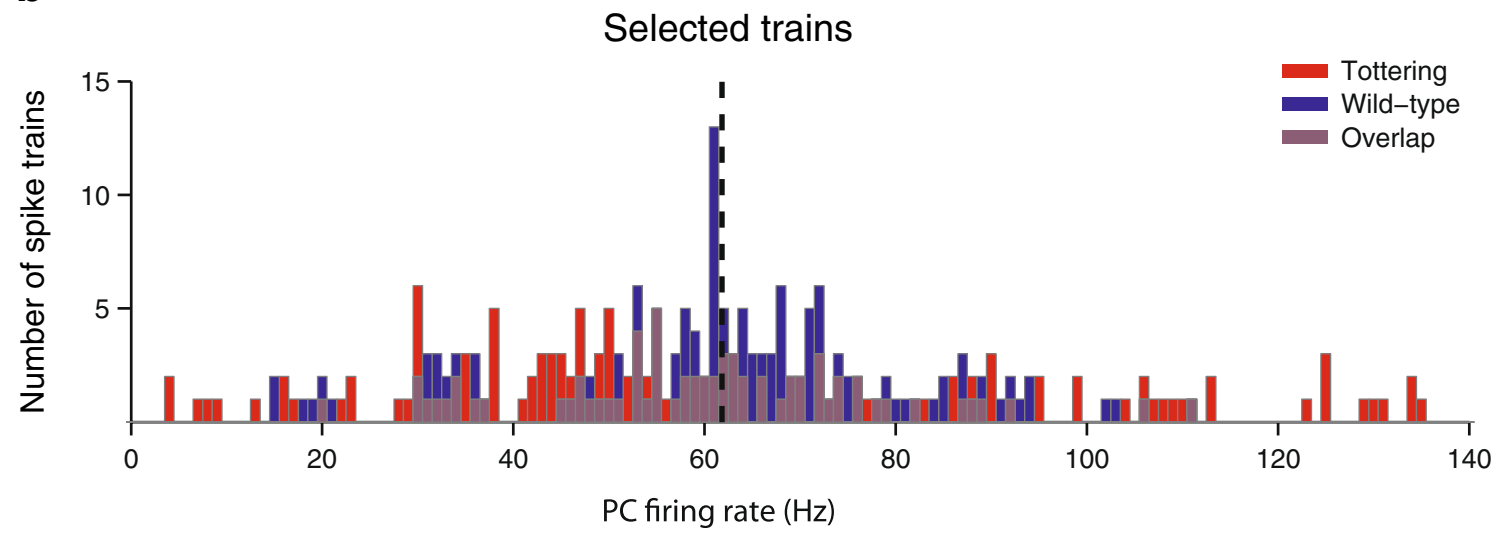

Fig. 3 Firing rate distributions before and after the selection of sets of trains with identical mean rates. a Distribution of spike rates for the original set of 326 tottering and 251 wild-type trains divided into 15 -s stretches. The dashed lines indicate the different mean rates of

based on anatomical evidence ([13-15]; CIDZ, unpublished data), but they might be generated dynamically by temporary synchronisation of the Purkinje cells converging onto the $\mathrm{CN}$ neuron. At a convergence ratio of 1 , the $\mathrm{CN}$ neuron model still responded with a faster spike rate to the irregular spike trains from tottering Purkinje cells than to the more regular trains from wild-type cells (Fig. 4a, left). However, the irregularity induced acceleration of $\mathrm{CN}$ spiking at a convergence of 1 occurred to the same extent both in the presence and absence of STD. With STD at the inhibitory synapses, irregular input from tottering Purkinje cells resulted in a $25.8 \%$ increase in $\mathrm{CN}$ neuron spike rate compared to the $\mathrm{CN}$ neuron response to more regular input from wild-type Purkinje cells (tottering, $81.0 \pm 22.8 \mathrm{~Hz}$; wild type, $64.4 \pm 15.6 \mathrm{~Hz}, n=204)$. The same relative increase of $25.8 \%$ in spike rate in response to tottering relative to wild-type input spike trains was found when STD was switched off (tottering, $78.5 \pm 25.3 \mathrm{~Hz}$; wild type, 62.4 \pm $18.1 \mathrm{~Hz}, n=204)$. Thus, when the $\mathrm{CN}$ neuron received input from a single Purkinje cell, or for completely synchronised Purkinje cell input, the Purkinje cell input irregularity is tottering (red) and wild-type (blue) trains before selection. b Spike rates of one of 204 selected sets of 15015 -s trains from tottering and wild-type Purkinje cells, with a mean rate of $61.8 \mathrm{~Hz}$ for both tottering and wild type (black dashed line)

recoded as $\mathrm{CN}$ output firing rate in an STD-independent manner. Intermediate convergence ratios between one and 150 Purkinje cells per $\mathrm{CN}$ neuron resulted in irregularity induced spike rate increases that were partially dependent on STD, with an increasing contribution of STD to the spike rate acceleration for increasing convergence ratios (Fig. 4a and Supplementary Fig. 1).

Effect of Purkinje Cell Irregularity on Mean and Variance of the Inhibitory Conductance

To identify potential mechanisms of the irregularity induced acceleration of spike rate, we measured the mean and the variance of the total $\mathrm{GABA}_{\mathrm{A}}$ conductance injected by the tottering and wild-type spike trains through all 450 inhibitory synapses into the $\mathrm{CN}$ neuron model in simulations in the presence and absence of STD at different convergence ratios (Fig. $4 \mathrm{~b}, \mathrm{c}$ ). At a convergence ratio of 150 , the presence of STD resulted in a $16.0 \%$ reduction of the mean $\mathrm{GABA}_{\mathrm{A}}$ conductance injected by the tottering spike trains into the $\mathrm{CN}$ model compared to the wild-type 
Fig. 4 The $\mathrm{CN}$ neuron model responds with faster spiking to irregular spike trains from tottering Purkinje cells. a Spike rates of the $\mathrm{CN}$ neuron model in response to spike trains from tottering and wild-type Purkinje cells in the presence and absence of STD and for different Purkinje cell convergence ratios. The input irregularity driven acceleration of output spike rate depends on the presence of STD for high convergence ratios, but becomes independent of STD for low convergence ratios. b Mean of the total $\mathrm{GABA}_{\mathrm{A}}$ conductance injected into the $\mathrm{CN}$ neuron model by the spike trains used in a. c Variance of the total $\mathrm{GABA}_{\mathrm{A}}$ conductance injected into the $\mathrm{CN}$ neuron model by the spike trains used in a. Errors are given as standard errors of the mean $(n=204)$
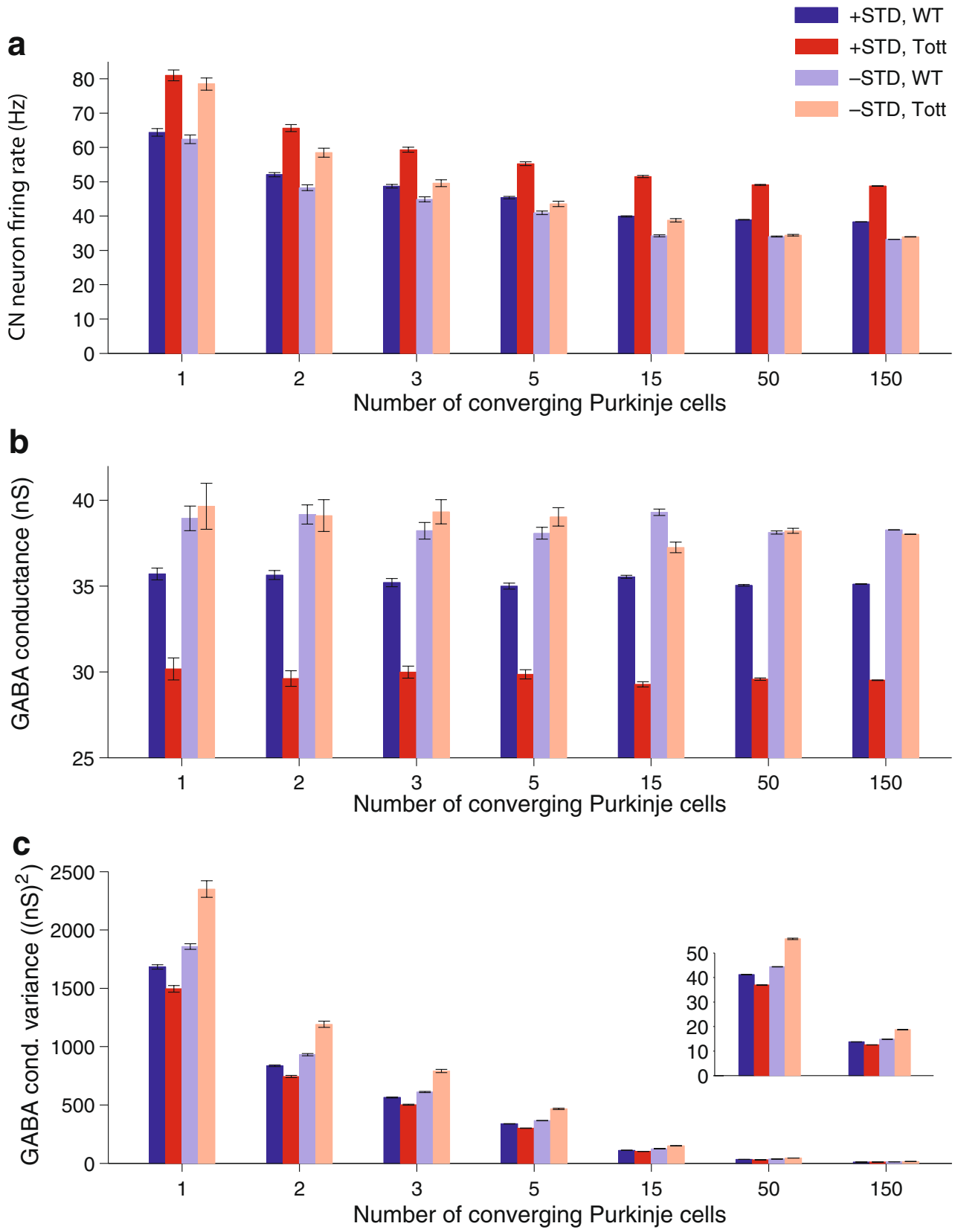

trains (tottering, $29.5 \pm 0.3 \mathrm{nS}$; wild type, $35.1 \pm 0.1 \mathrm{nS}, n=$ 204). Without STD, the difference between the mean conductances injected by tottering and wild-type spike trains at a convergence ratio of 150 was reduced to $0.8 \%$ (tottering, $38.0 \pm 0.2 \mathrm{nS}$; wild type, $38.3 \pm 0.2 \mathrm{nS}, n=204$ ). Not surprisingly, the mean conductance values were similar at all convergence ratios (Fig. 4b). For a convergence of one Purkinje cell per $\mathrm{CN}$ neuron, the irregularity dependent conductance decrease was $15.4 \%$ in the presence of STD (tottering, $30.2 \pm 9.2 \mathrm{nS}$; wild type, $35.7 \pm 5.0 \mathrm{nS}, n=204$ ), while only a small increase of $1.8 \%$ of the conductance occurred in the absence of STD (tottering, $39.6 \pm 19.1 \mathrm{nS}$; wild type, $38.9 \pm 10.3 \mathrm{nS}, n=204)$.
To understand why the irregular spike trains from tottering Purkinje cells injected less inhibitory conductance into the CN neuron model than the more regular trains from wild-type cells, and why this irregularity driven conductance decrease depended on the presence of STD, we examined example responses of the $\mathrm{CN}$ model to spike trains from tottering and wild-type cells. As illustrated for a convergence ratio of 150 in Fig. 5, the irregular spike trains from tottering Purkinje cells contained a larger proportion of short ISIs than the wild-type trains, leading to stronger STD of the inhibitory conductance (Fig. 5a, b). Thus, STD acted as a low-pass filter by selectively decreasing the effect of the high-frequency components of the input spike trains. The more regular 
a

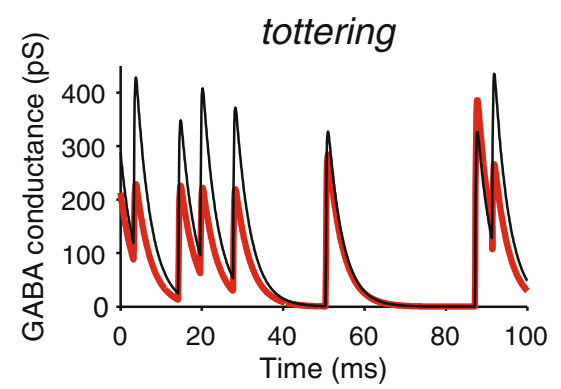

b
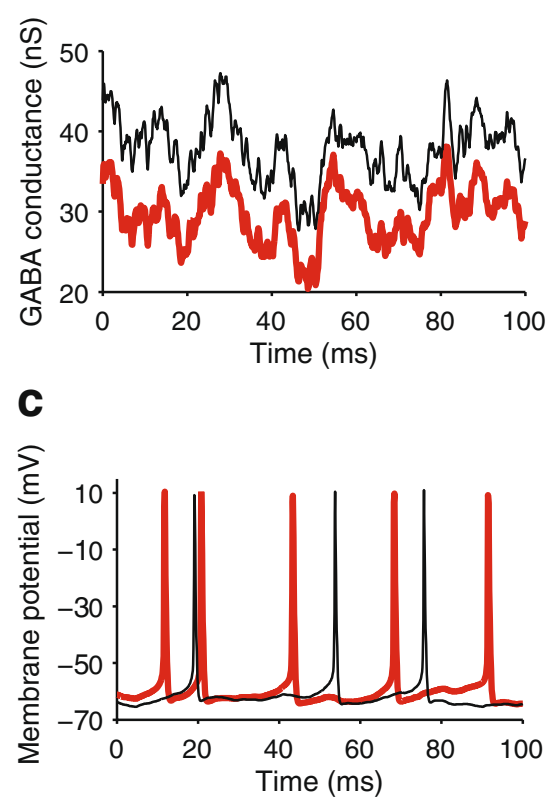

Fig. 5 Responses of the $\mathrm{CN}$ neuron model to spike trains from tottering and wild-type Purkinje cells at high convergence ratios. Example responses of the $\mathrm{CN}$ neuron model to tottering (left column) and wild type (right) inputs in the presence (red traces) and absence (black) of STD and for a convergence ratio of 150 are shown. The selected time interval is a $100 \mathrm{~ms}$ stretch from a $15 \mathrm{~s}$ long simulation and represents the same time period in all panels $\mathbf{a}-\mathbf{f}$. a and $\mathbf{d}$ Conductance traces of one of the $450 \mathrm{GABA}_{\mathrm{A}}$ synapses, showing the stronger effect of STD in tottering (a) than in wild type (d), which is due to the more frequent occurrence of shorter ISIs in the irregular

Purkinje cell spike trains from wild-type mice contained a smaller number of short ISIs and were therefore less affected by the STD-dependent low-pass filtering, which resulted in a reduced depression of the inhibitory conductance (Fig. 5d, e). The decrease of the inhibitory conductance in response to tottering spike trains in the presence of STD was reflected by an increase in $\mathrm{CN}$ neuron firing rate compared to responses to tottering trains without STD and to wild-type trains with and without STD (Fig. 5c, f; cf Fig. 4a).

Thus, at a convergence ratio of 150 , the STDdependence of the irregularity driven decrease of the inhibitory conductance can explain that the increased d

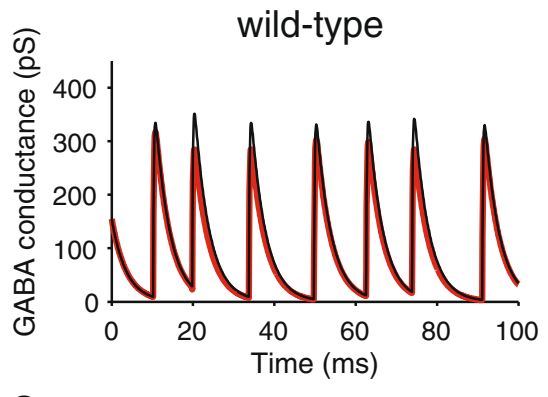

e
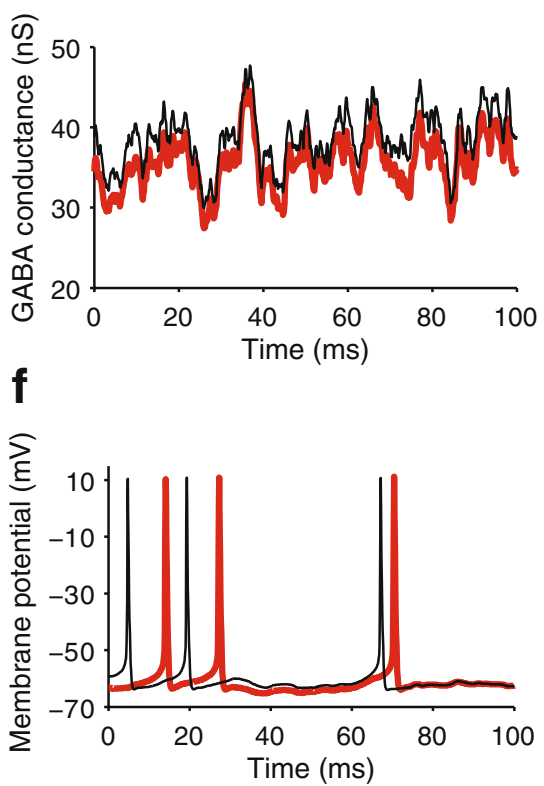

tottering trains. $\mathbf{b}$ and $\mathbf{e}$ Same as a and $\mathbf{d}$ but showing the summed conductance of all $\mathrm{GABA}_{\mathrm{A}}$ synapses. $\mathbf{c}$ and $\mathbf{f}$ Voltage traces in response to tottering and wild-type trains, recorded at the soma. In the presence of STD, input from tottering Purkinje cells results in five $\mathrm{CN}$ spikes in the 100-ms interval, corresponding to a firing rate of $50 \mathrm{~Hz}$. In the three other simulations (tottering without STD and wild type with and without STD), the CN neuron model only fires three spikes, corresponding to $30 \mathrm{~Hz}$. This agrees with the overall result from a convergence of 150 shown in Fig. 4 (49 vs. $33-38 \mathrm{~Hz}$ )

irregularity of the tottering trains resulted in an STDdependent acceleration of $\mathrm{CN}$ neuron spiking compared to wild-type trains. However, at a convergence ratio of 1 , input from tottering Purkinje cells led to accelerated $\mathrm{CN}$ neuron spiking both in the presence and absence of STD (Fig. 4a), whereas the reduction of the inhibitory conductance only occurred when STD was present. This implies that other mechanisms must be involved in the irregularity based spike rate acceleration at a convergence of 1 .

For excitatory synaptic inputs, it has been established that the gain of the input-output relationship of a neuron can be affected by changes in the variance of its inputs 
(reviewed in [23]). We therefore examined if irregularity based changes in the variance of the total $\mathrm{GABA}_{\mathrm{A}}$ conductance summed over all 450 inhibitory synapses could contribute to the irregularity driven spike rate increases at different convergence ratios (Fig. 4c). At a convergence ratio of 1 , all inhibitory synapses received input from identical spike trains, which resulted in large fluctuations of the total conductance and large values of the conductance variance. In the presence of STD, input from tottering and wild-type spike trains led to conductance

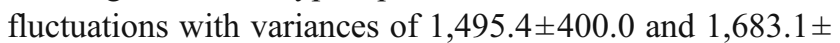
$271.0 \mathrm{nS}^{2}$, respectively, corresponding to an irregularity based variance decrease of $11.2 \%(n=204)$. Without STD, input from tottering spike trains resulted in a conductance variance that was increased by $26.5 \%$ compared to the

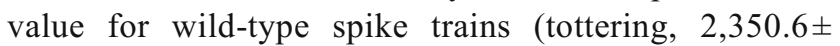
$1,011.7 \mathrm{nS}^{2}$; wild type, $\left.1,857.7 \pm 344.0 \mathrm{nS}^{2}, n=204\right)$. For a convergence ratio of 150 , the relative differences in conductance variance between simulations with tottering and wild-type spike trains were in a similar range; the increased irregularity of the tottering trains caused a conductance variance decrease of $8.8 \%$ in the presence of STD and an increase of $26.2 \%$ in the absence of STD. However, the summation of 150 distinct conductance trains resulted in absolute values of the conductance variance that were much smaller than the values for a convergence of one (+STD: tottering, $10.3 \pm 0.4 \mathrm{nS}^{2}$; wild type, $11.3 \pm 0.1 \mathrm{nS}^{2}, n=$ 204; -STD: tottering, $15.4 \pm 0.8 \mathrm{nS}^{2}$; wild type, $12.2 \pm$ $\left.0.2 \mathrm{nS}^{2}, n=204\right)$. These results indicate that the increase in conductance variance that occured for tottering spike trains at a convergence ratio of one in the absence of STD might contribute to the STD-independent irregularity driven spike rate acceleration at this low convergence.

\section{Effect of Purkinje Cell Irregularity on Other Features of the CN Neuron Spike Response}

To explore other potential mechanisms for the STDindependent encoding of Purkinje cell irregularity as $\mathrm{CN}$ neuron spike rate at low convergence ratios, we studied the effect of the increased irregularity of the spike trains from

Fig. 6 Input from tottering Purkinje cells allows periods of regular activity in the $\mathrm{CN}$ neuron model at low convergence ratios. a Response of the $\mathrm{CN}$ model to a spike train from a tottering Purkinje cell (black bars) at a convergence ratio of 1. A pause in Purkinje cell activity results in a period of fast regular spiking in the $\mathrm{CN}$ neuron model. b Same as a but for wild-type Purkinje cell input. c Effect of the convergence ratio on the fraction of the $\mathrm{CN}$ spike trains comprising patterns of regular firing $(\geq 4$ consecutive ISIs with a $\mathrm{CV}_{2} \leq 0.2$, see "Materials and Methods" section). At a convergence ratio of 1 , input from tottering Purkinje cells increases the occurrence of fast regular patterns in the $\mathrm{CN}$ spike trains compared to input from wild-type Purkinje cells, independently of the presence of STD. Errors are given as standard errors of the mean $(n=204)$ a Tott PC| || ||||||| ||| ||||||||||| | || ||| ||| |

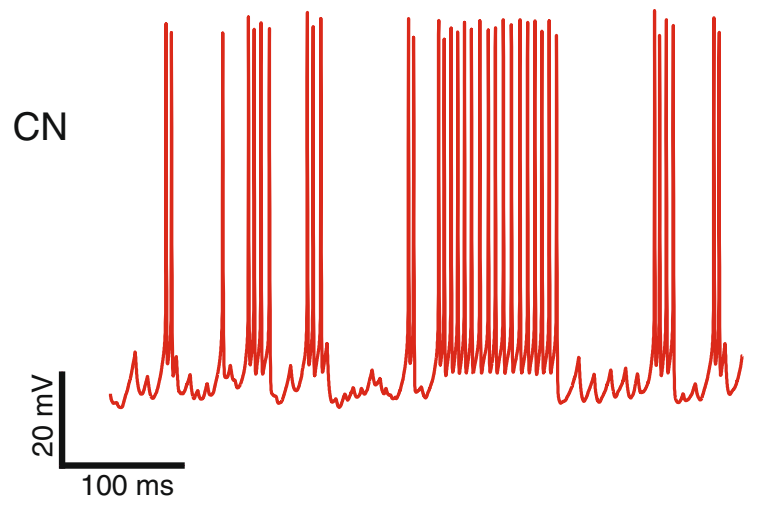

b WT PC | || |||||| || || || || ||||||||||||

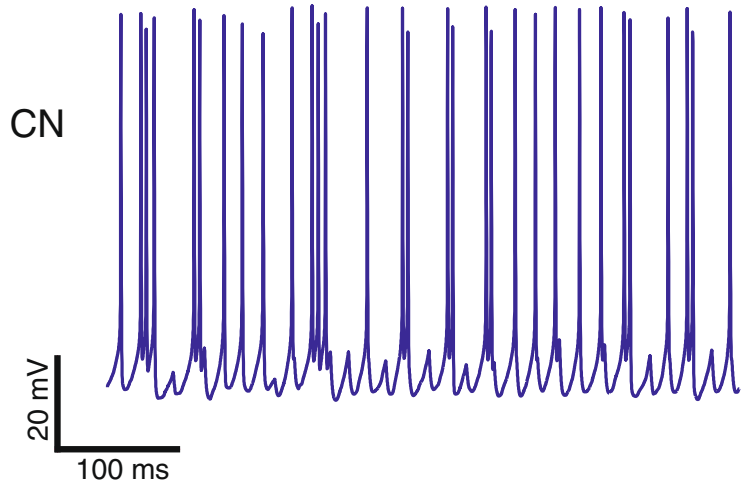

C

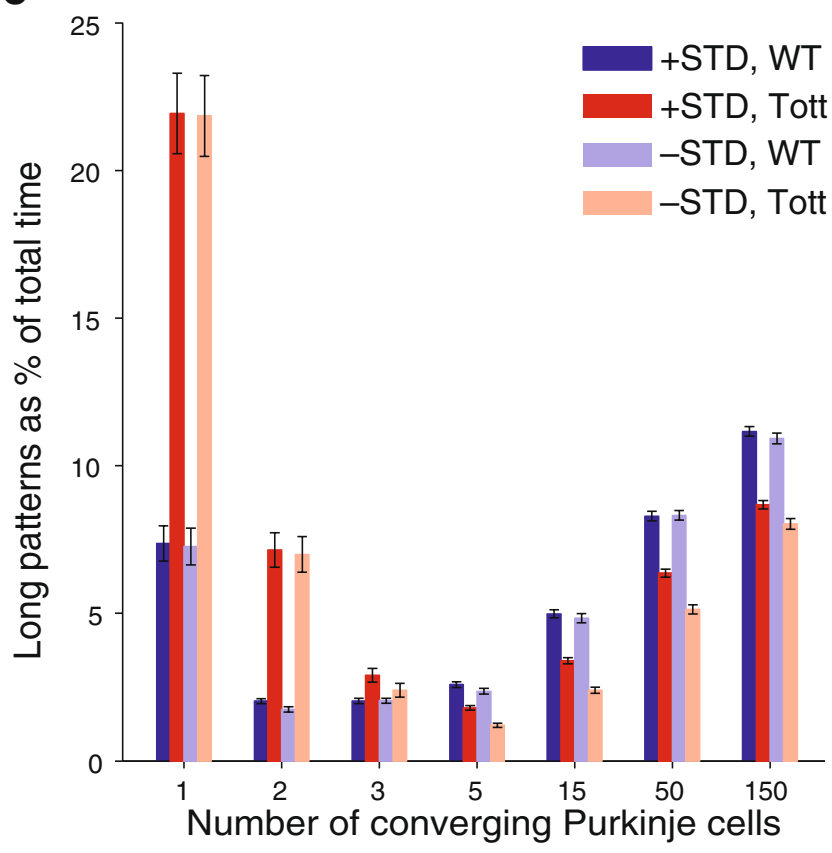


tottering Purkinje cells on the temporal micro-structure of the $\mathrm{CN}$ neuron spike response. Figure $6 \mathrm{a}$, b shows example spike trains from a tottering and a wild-type Purkinje cell and how the $\mathrm{CN}$ neuron model responds to these spike trains at a convergence ratio of 1 . These traces illustrate another consequence of the irregular structure of the spike trains from tottering Purkinje cells; in addition to containing a larger number of short ISIs than spike trains from wildtype Purkinje cells (Fig. 5a, d), they also contained longer pauses in spiking. At a convergence ratio of 1 , these pauses in inhibitory input were synchronised and allowed patterns of regular $\mathrm{CN}$ neuron spiking that were driven by a combination of excitatory input from mossy fibre collaterals and the intrinsic pacemaking activity of the $\mathrm{CN}$ neuron. Independent of the presence of STD, the increased irregularity of the spike trains from tottering Purkinje cells therefore resulted in nearly $200 \%$ increases in the proportion of the resulting $\mathrm{CN}$ spike trains that comprised long regular patterns of four or more consecutive ISIs with a $\mathrm{CV}_{2} \leq 0.2$ [19] (+STD: tottering, $21.9 \pm 19.5 \%$; wild type, $7.4 \pm 8.6 \%, n=204$; - STD: tottering, $21.8 \pm 19.6 \%$; wild type, $7.3 \pm 8.9 \%, n=204$; Fig. $6 c$, see "Materials and Methods" section). Thus, synchronised pauses in Purkinje cells activity and the resulting patterns of fast regular $\mathrm{CN}$ spiking could also contribute to the STD-independent increase in $\mathrm{CN}$ neuron spike rate in response to the irregular spike trains from tottering Purkinje cells that occurred at a convergence ratio of 1 .

We also quantified the effect of the increased irregularity of spike trains from tottering Purkinje cells on the CVof the CN neuron spike output (Supplementary Fig. 2). In all cases, the increased irregularity of the inhibitory input resulted in an increased CV of the $\mathrm{CN}$ neuron spike trains. This effect was most pronounced for a convergence ratio of 1 (+STD: tottering, $1.01 \pm 0.28$; wild type, $0.75 \pm 0.08, n=204$; $-\mathrm{STD}$ : tottering, $1.20 \pm 0.46$; wild type, $0.80 \pm 0.13, n=204)$ but still present for a convergence ratio of 150 ( + STD: tottering, $0.34 \pm 0.01$; wild type, $0.32 \pm 0.00, n=204$; $-\mathrm{STD}$ : tottering, $0.34 \pm 0.01$; wild type, $0.32 \pm 0.01, n=204$ ).

\section{Parameter Sensitivity}

Due to the limited number of available Purkinje cell spike trains from tottering and wild-type mice, our analysis of the input irregularity dependent acceleration of $\mathrm{CN}$ neuron output spike rate in response to real spike trains from anaesthetised mice was restricted to a single mean Purkinje cell firing rate of $62 \mathrm{~Hz}$ and convergence ratios of up to 150. However, the exact convergence ratio is not known and Purkinje cells in vivo can fire simple spikes at rates between 10 and more than $100 \mathrm{~Hz}$ [38-43].

To explore the dependence of the $\mathrm{CN}$ neuron response on Purkinje cell spike rate and convergence ratio, we presented the $\mathrm{CN}$ neuron model with artificially generated inhibitory input spike trains with firing rates between 10 and $150 \mathrm{~Hz}$ and convergence ratios between 1 and 450 (Fig. 7). For a convergence ratio of 90, an STD-dependent acceleration in output firing rate with increasing input irregularity occurred over the whole range of input spike rates tested, but was most pronounced for intermediate spike rates between 30 and $120 \mathrm{~Hz}$, which are commonly observed in Purkinje cells (Fig. 7a). Varying the convergence ratio affected the amount of the STD-dependent increase in $\mathrm{CN}$ neuron spike rate with larger STDdependent spike rate increases for larger numbers of Purkinje cells converging onto the $\mathrm{CN}$ neuron (shown for input spike rates of $60 \mathrm{~Hz}$ in Fig. 7b). These observations confirmed the results obtained with spike trains from tottering and wild-type Purkinje cells, although a small STD dependence of the spike rate increase remained even for a convergence ratio of 1 . The discrepancy between the small STD-dependent spike rate increase at a convergence ratio of 1 for artificial input trains and the STD-independent spike rate increase in response to spike trains from tottering Purkinje cells can be explained by the larger number of long pauses in spiking in the latter. We did not test any convergence ratios of more than 450 as the $\mathrm{CN}$ neuron model only included 450 inhibitory synapses, but the magnitude of the STD effect was already near maximum for a convergence ratio of 45 (Fig. 7b) so larger convergence ratios are not expected to have any additional effect.

Moreover, we studied how the recoding of input irregularity as output spike rate depended on the intrinsic properties of the $\mathrm{CN}$ neuron. A characteristic feature of $\mathrm{CN}$ neurons are rebound spike responses to inhibitory synaptic input and hyperpolarising current injections, which are mediated by a Cav3.1 LVA current, a NaP current and an $\mathrm{HCN}$ current [24]. We performed control simulations where these three currents were eliminated from the $\mathrm{CN}$ neuron model and found that the input irregularity dependent spike rate increases and the proportion of time spent in long regular patterns were robust against these changes (Supplementary Fig. 3).

\section{Discussion}

The cerebellar nuclei provide the main gateway from the cerebellum to the rest of the brain but their contribution to neural coding and information processing in the cerebellum remains an open question. In particular, how neurons in the $\mathrm{CN}$ integrate inhibitory inputs from Purkinje cells in the cerebellar cortex with excitatory inputs from mossy fibre and climbing fibre collaterals is not fully understood. We have used a biologically detailed conductance-based model of an excitatory projection neuron in the $\mathrm{CN}$ to study the transformation of Purkinje cell activity into $\mathrm{CN}$ neuron 

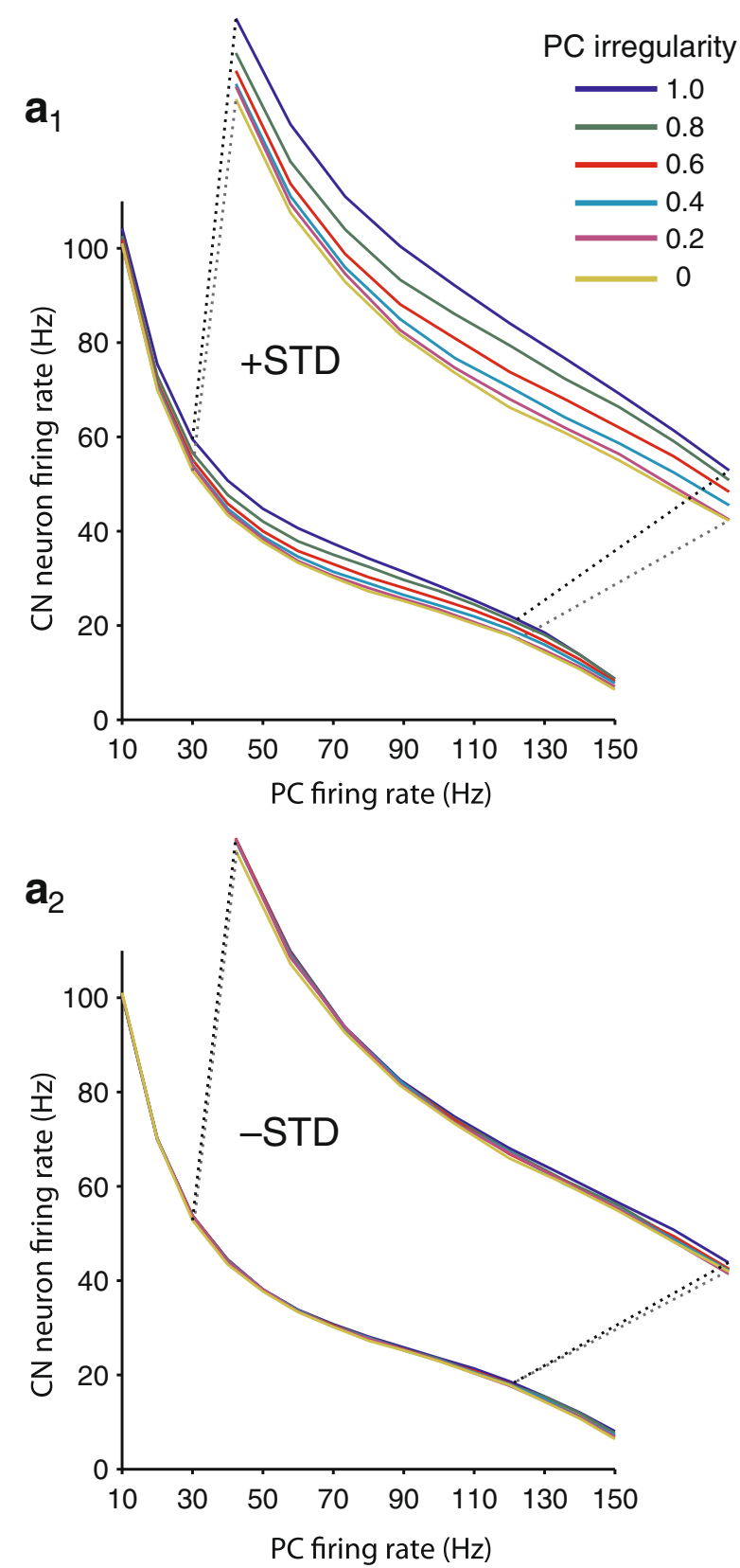

b

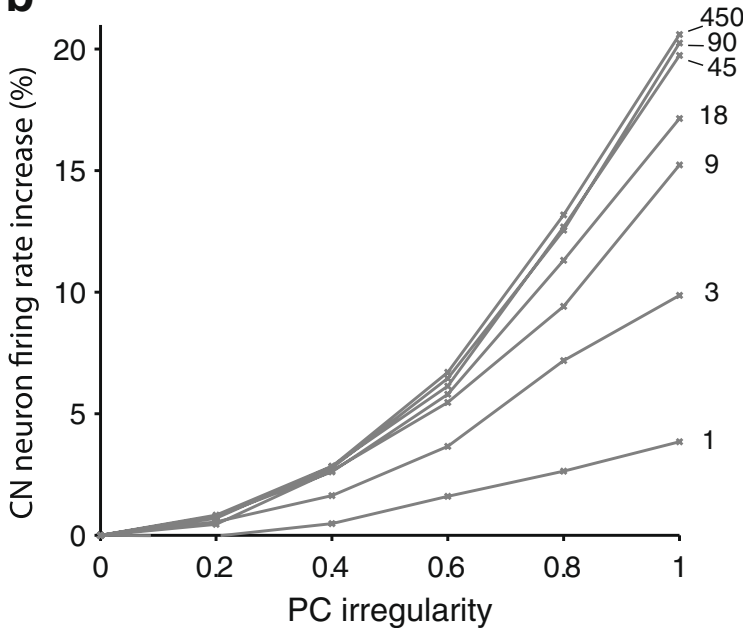

Fig. $7 \mathrm{CN}$ spike rate increases for a wide range of input spike rates and dependence of the STD effect on the convergence ratio. a Effect of input irregularity on the $\mathrm{CN}$ neuron model at different firing rates of the Purkinje cell inputs in the presence $\left(a_{1}\right)$ and absence $\left(a_{2}\right)$ of STD (convergence ratio $=90$ ). b STD-dependent relative increase of the $\mathrm{CN}$ neuron spike rate $\left(\left(\mathrm{STD}_{\mathrm{ON}}-\mathrm{STD}_{\mathrm{OFF}}\right) / \mathrm{STD}_{\mathrm{OFF}}\right)$ for different convergence ratios (at a Purkinje cell spike rate of $60 \mathrm{~Hz}$ ). The STD dependence of the irregularity driven spike rate increase is diminished for low-convergence ratios

output. Our main finding is that $\mathrm{CN}$ neurons can encode the degree of irregularity in their inhibitory input as output firing rate. This transformation of input irregularity into output spike rate was found in response to both artificially generated input spike trains and spike trains recorded in vivo from Purkinje cells in awake tottering and wild-type mice, and it was robust in the presence of a wide range of Purkinje cell input spike rates.

\section{Different Mechanisms Operate at Different Convergence Ratios}

The mechanisms underlying the input irregularity driven increase in output spike rate depended on the number of functionally distinct Purkinje cells converging onto a single $\mathrm{CN}$ neuron. For a large convergence ratio of Purkinje cells per $\mathrm{CN}$ neuron, and in the absence of synchronised Purkinje cell activity, the recoding of input irregularity as output firing rate was mediated by STD at the Purkinje cell to $\mathrm{CN}$ neuron synapse and based on a decrease in inhibitory synaptic conductance in response to irregular input spike trains (Fig. 4b). For smaller convergence ratios, the contribution of STD to the firing rate increase was reduced; and for a convergence ratio of 1 , or for fully synchronised Purkinje cell input, the irregularity based spike rate acceleration occurred to the same extent in the presence and absence of STD. Several candidate mechanisms could contribute to the recoding of Purkinje cell irregularity as $\mathrm{CN}$ neuron spike rate at very low convergence ratios. In the presence of STD, the decreased inhibitory conductance (Fig. 4b) could lead to accelerated $\mathrm{CN}$ neuron spiking. In the absence of STD, the spike rate increase could be driven by the increase in the variance of the inhibitory conductance that is caused by irregular input spike trains (Fig. 4c). Moreover, independent of STD, the synchronisation of pauses in Purkinje cell activity across all inhibitory synapses allows periods of fast regular spiking in the $\mathrm{CN}$ neuron and could therefore contribute to the increase in firing rate in response to irregular input (Fig. 6). These synchronised pauses in the inhibitory input, as well as the increased variance of the inhibition, can also explain that the $\mathrm{CN}$ neuron spike rate increased when the convergence ratio was reduced, with a maximum spike rate at a convergence ratio of 1 (Fig. 4a). However, convergence ratios of 1 and completely synchronised Purkinje cell input 
to $\mathrm{CN}$ neurons have never been reported in the literature and the STD-dependent recoding of input irregularity as output firing rate at high convergence ratios is more likely to be relevant in vivo.

\section{Implications for Motor Control}

Tottering mice suffer from disrupted regularities of their Purkinje cell spiking, while the amplitude modulation of their spike rate during optokinetic stimulation is indistinguishable from that in wild-type littermates [20]. Since they also show impaired motor behaviour including an abnormal optokinetic reflex (OKR), these data indicate that the regularity of Purkinje cell spiking is relevant for motor control. At the same time, these results raise the question as to how the degree of regularity in Purkinje cell activity can be read out by neurons downstream. As the postsynaptic target neurons of the Purkinje cells in the $\mathrm{CN}$ fire at higher rates in anesthetised tottering mice than in wild-type ones [37], the effect of the increased Purkinje cell irregularity on impaired motor control might be caused by an increased $\mathrm{CN}$ neuron spike rate. Although this needs to be confirmed by recording from $\mathrm{CN}$ neurons in awake mice, our simulations predict that the increased $\mathrm{CN}$ neuron spike rate in tottering mice can be caused directly by the increased irregularity in the Purkinje cell activity. Moreover, the data are in line with the finding that for biologically realistic convergence ratios of 100 or more Purkinje cells per $\mathrm{CN}$ neuron ([13-15]; CIDZ, unpublished data), the Purkinje cell irregularities affect $\mathrm{CN}$ neuron spike rate. We therefore argue that the motor control deficits in tottering mice may depend at least partially on STD at the synapses between Purkinje cells and CN neurons and that any pharmacological modulation that blocks STD at these synapses is likely to alleviate the motor performance deficits in these mutants.

\section{Limitations of the Simulations}

The mutation that characterises tottering mutants leads to a complex phenotype comprising a number of morphological and physiological alterations compared to wild-type mice. Tottering Purkinje cells show a reduced calcium channel current density and diminished calcium influx [44], a reduction in the amplitude of parallel fibre evoked excitatory postsynaptic potentials [45] and an increased sensitivity to modulation by inhibitory interneurons [46]. Their somata are smaller and contain elongated nuclei [47, 48] and their dendritic spines make frequent multiple contacts with single parallel fibre varicosities [49]. These alterations could contribute to and are reflected by the irregular spike pattern that characterises the activity of tottering Purkinje cells in vivo [20]. However, other alterations exist that could influence how the somatically recorded spike trains of tottering Purkinje cells affect their target neurons in the $\mathrm{CN}$. Although the synapses between Purkinje cells and $\mathrm{CN}$ neurons in tottering mice are functionally intact and their density is indistinguishable from the synaptic density in wild-type mice, the size of the tottering Purkinje cell synaptic terminals is increased and they contain an increased number of swollen mitochondria and pathological vacuoles [37]. Purkinje cell axons of older ( $>6$ months) tottering mice can also exhibit swelling and contain pathological organelles and microtubules [47, 49]. These alterations could affect the Purkinje cell input that is transmitted to the $\mathrm{CN}$ neurons and contribute to the accelerated $\mathrm{CN}$ neuron firing rate [37]. Moreover, the use of anaesthesia could have influenced the firing rate of the $\mathrm{CN}$ neurons [50] and it should be investigated in experiments if STD at the Purkinje cell onto $\mathrm{CN}$ neuron synapses is affected in tottering mice. Ideally, the existence and spike rate dependence of STD in tottering and wild-type mice should be studied in physiologically relevant preparations, as it has been shown that data on synaptic release probabilities and STD induction are not always transferable from slice recordings to the in vivo situation [51].

Another question that remains is whether there are morphological or physiological changes in the tottering $\mathrm{CN}$ neurons themselves that could influence their spike activity. CN neurons express P/Q-type voltage-gated calcium channels [52-54], although these channels seem to have a very small effect on their excitability [55]. We used the same CN neuron model for simulations with spike trains from tottering and wild-type Purkinje cells and we did not change any synaptic characteristics. The reason for this simplified modelling approach is that our goal was not to build a faithful model of the neural network connecting Purkinje cell and $\mathrm{CN}$ neurons in tottering mice, but to investigate whether the combination of irregular Purkinje cell activity and STD at the Purkinje cell onto CN neuron synapse could provide a parsimonious explanation for the altered $\mathrm{CN}$ neuron firing. Our results show that a combination of irregular input and STD is sufficient to generate an increase in output rate, but it will be interesting to investigate both in electrophysiological experiments and computer simulations how other morphological and physiological changes in tottering mice contribute.

\section{Other Forms of Neural Coding in the Cerebellar Nuclei}

The focus of the present study was to investigate how irregular Purkinje cell activity can influence the steady-state spike rate of $\mathrm{CN}$ neurons. In all simulations, the $\mathrm{CN}$ neuron model was presented with Purkinje cell input over extended time periods during which the input spike rate and the input irregularity were kept constant. However, Purkinje cells spike trains in vivo exhibit temporal fluctuations in spike 
rate and irregularity and they are characterised by periods of regular spiking that are interspersed with pauses [19]. Bursts of inhibitory synaptic inputs that are followed by pauses can result in rebound spike responses in $\mathrm{CN}$ neurons $[11,12,56]$ (but see [57]). It has been suggested that the pauses in Purkinje cell activity set the timing of the rebound responses in $\mathrm{CN}$ neurons and participate in temporal coding, while the rate of Purkinje cell spiking preceding a pause determines the spike rate of the rebound response, forming a rate code [58]. Recently, it has also been shown that the rebound spike rate can encode the amplitude of Purkinje cell inhibition [56], which suggests that it might also carry information about the number of Purkinje cells providing concerted inhibition to the $\mathrm{CN}$ neurons. Thus, a $\mathrm{CN}$ neuron might employ a multitude of neural codes simultaneously or at different points in time.

\section{Computational Functions of STD}

Our results suggest that a potential computational function of STD at the Purkinje cell onto CN neuron synapse is the transformation of Purkinje cell irregularity into $\mathrm{CN}$ neuron spike rate, by low-pass filtering of high-frequency components in irregular Purkinje cell spike trains. This result is independent of the physiology of Purkinje cells and $\mathrm{CN}$ neurons and relevant for every depressing inhibitory synapse that receives irregular input spike trains. STD is commonly found in neural circuits and usually caused presynaptically by an activity dependent reduction of the readily releasable pool of neurotransmitter vesicles [59, 60], although desensitisation of postsynaptic receptors can also contribute [61, 62]. The low-pass filtering properties of synapses which exhibit STD have been described before [63-67] and they have been implicated in several other computations, including the generation of phase shifts in response to synaptic inputs [63-65], coincidence detection [68] and balancing excitatory and inhibitory inputs in cortical neurons [69]. Moreover, it has been reported that STD enables neurons to respond to relative rather than absolute changes in input rates [70] and it has recently been shown that STD can provide neurons with the ability to act as multiplicative devices and adjust the gain of their inputoutput relationship [71]. However, the functional role of STD in gain control has as yet only been shown for excitatory synapses onto cerebellar granule cells and cortical pyramidal cells. The computational implications of STD at inhibitory synapses in the cerebellum and other brain areas should be an exciting subject for future research.

Acknowledgements VS is supported by a Systems Biology Fellowship from the Biotechnology and Biological Sciences Research Council (F005490). We also kindly thank the Dutch Organization for Medical Sciences (ZonMw; CIDZ), Life Sciences (CIDZ, FEH),
Senter (Neuro-Bsik; CIDZ), Erasmus University Fellowship (FEH), Prinses Beatrix Fonds (CIDZ), and the SENSOPAC, CEREBNET and C7 programmes of the European Community (CIDZ) for their financial support.

Conflict of Interest Statement There are no potential conflicts of interest that might bias this work.

Open Access This article is distributed under the terms of the Creative Commons Attribution Noncommercial License which permits any noncommercial use, distribution, and reproduction in any medium, provided the original author(s) and source are credited.

\section{References}

1. Daniel H, Billard JM, Angaut P, Batini C. The interpositorubrospinal system. Anatomical tracing of a motor control pathway in the rat. Neurosci Res. 1987;5:87-112.

2. Fredette BJ, Mugnaini E. The GABAergic cerebello-olivary projection in the rat. Anat Embryol (Berl). 1991;184:225-43.

3. Teune TM, van der Burg J, van der Moer J, Voogd J, Ruigrok TJ. Topography of cerebellar nuclear projections to the brain stem in the rat. Prog Brain Res. 2000;124:141-72.

4. Czubayko U, Sultan F, Thier P, Schwarz C. Two types of neurons in the rat cerebellar nuclei as distinguished by membrane potentials and intracellular fillings. J Neurophysiol. 2001;85:2017-29.

5. Sultan F, Czubayko U, Thier P. Morphological classification of the rat lateral cerebellar nuclear neurons by principal component analysis. J Comp Neurol. 2003;455:139-55.

6. Uusisaari M, Obata K, Knopfel T. Morphological and electrophysiological properties of GABAergic and non-GABAergic cells in the deep cerebellar nuclei. J Neurophysiol. 2007;97:901-11.

7. Uusisaari M, Knopfel T. GABAergic synaptic communication in the GABAergic and non-GABAergic cells in the deep cerebellar nuclei. Neuroscience. 2008;156:537-49.

8. Uusisaari M, Knopfel T. GlyT2+ neurons in the lateral cerebellar nucleus. Cerebellum. 2010;9:42-55.

9. Gardette R, Debono M, Dupont JL, Crepel F. Electrophysiological studies on the postnatal development of intracerebellar nuclei neurons in rat cerebellar slices maintained in vitro. II. Membrane conductances. Brain Res. 1985;352:97-106.

10. Gardette R, Debono M, Dupont JL, Crepel F. Electrophysiological studies on the postnatal development of intracerebellar nuclei neurons in rat cerebellar slices maintained in vitro. I. Postsynaptic potentials. Brain Res. 1985;351:47-55.

11. Aizenman CD, Linden DJ. Regulation of the rebound depolarization and spontaneous firing patterns of deep nuclear neurons in slices of rat cerebellum. J Neurophysiol. 1999;82:1697-709.

12. Tadayonnejad R, Mehaffey WH, Anderson D, Turner RW. Reliability of triggering postinhibitory rebound bursts in deep cerebellar neurons. Channels (Austin). 2009;3:149-55.

13. De Zeeuw CI, Wylie DR, DiGiorgi PL, Simpson JI. Projections of individual Purkinje cells of identified zones in the flocculus to the vestibular and cerebellar nuclei in the rabbit. J Comp Neurol. 1994;349:428-47.

14. De Zeeuw CI, Berrebi AS. Postsynaptic targets of Purkinje cell terminals in the cerebellar and vestibular nuclei of the rat. Eur J Neurosci. 1995;7:2322-33.

15. Palkovits M, Mezey É, Hámori J, Szentágothai J. Quantitative histological analysis of the cerebellar nuclei in the cat. I. Numerical data on cells and on synapses. Exp Brain Res. 1977;28:189-209. 
16. Telgkamp P, Raman IM. Depression of inhibitory synaptic transmission between Purkinje cells and neurons of the cerebellar nuclei. J Neurosci. 2002;22:8447-57.

17. Pedroarena CM, Schwarz C. Efficacy and short-term plasticity at GABAergic synapses between Purkinje and cerebellar nuclei neurons. J Neurophysiol. 2003;89:704-15.

18. De Zeeuw CI, Hoebeek FE, Schonewille M. Causes and consequences of oscillations in the cerebellar cortex. Neuron. 2008;58:655-8.

19. Shin SL, Hoebeek FE, Schonewille M, de Zeeuw CI, Aertsen A, de Schutter E. Regular patterns in cerebellar Purkinje cell simple spike trains. PLoS One. 2007;2:e485.

20. Hoebeek FE, Stahl JS, van Alphen AM, Schonewille M, Luo C, Rutteman M, et al. Increased noise level of Purkinje cell activities minimizes impact of their modulation during sensorimotor control. Neuron. 2005;45:953-65.

21. Walter JT, Alvina K, Womack MD, Chevez C, Khodakhah K. Decreases in the precision of Purkinje cell pacemaking cause cerebellar dysfunction and ataxia. Nat Neurosci. 2006;9:389-97.

22. Green MC, Sidman RL. Tottering-a neuromuscular mutation in the mouse. And its linkage with oligosyndactylism. J Hered. 1962;53:233-7.

23. Silver RA. Neuronal arithmetic. Nat Rev Neurosci. 2010;11:47489.

24. Steuber V, Schultheiss N, Silver RA, De Schutter E, Jaeger D. Determinants of synaptic integration and heterogeneity in rebound firing explored with data-driven models of deep cerebellar nucleus cells. J Comp Neurosci. 2011;30(3):633-58.

25. Hines ML, Carnevale NT. The NEURON simulation environment. Neural Comput. 1997;9:1179-209.

26. Bower JM, Beeman D. The book of GENESIS: exploring realistic neural models with the GEneral NEural SImulation System. New York: Springer; 1998.

27. Hille B. Ion channels of excitable membranes. Sunderland, MA, USA: Sinauer; 2001.

28. Otis TS, Mody I. Modulation of decay kinetics and frequency of GABAA receptor-mediated spontaneous inhibitory postsynaptic currents in hippocampal neurons. Neuroscience. 1992;49:13-32.

29. Silver RA, Colquhoun D, Cull-Candy SG, Edmonds B. Deactivation and desensitization of non-NMDA receptors in patches and the time course of EPSCs in rat cerebellar granule cells. J Physiol. 1996;493:167-73.

30. Pugh JR, Raman IM. Potentiation of mossy fiber EPSCs in the cerebellar nuclei by NMDA receptor activation followed by postinhibitory rebound current. Neuron. 2006;51:113-23.

31. Pugh JR, Raman IM. Mechanisms of potentiation of mossy fiber EPSCs in the cerebellar nuclei by coincident synaptic excitation and inhibition. J Neurosci. 2008;28:10549-60.

32. Anchisi D, Scelfo B, Tempia F. Postsynaptic currents in deep cerebellar nuclei. J Neurophysiol. 2001;85:323-31.

33. Gauck V, Jaeger D. The contribution of NMDA and AMPA conductances to the control of spiking in neurons of the deep cerebellar nuclei. J Neurosci. 2003;23:8109-18.

34. Telgkamp P, Padgett DE, Ledoux VA, Woolley CS, Raman IM. Maintenance of high-frequency transmission at purkinje to cerebellar nuclear synapses by spillover from boutons with multiple release sites. Neuron. 2004;41:113-26.

35. Holt GR, Softky WR, Koch C, Douglas RJ. Comparison of discharge variability in vitro and in vivo in cat visual cortex neurons. J Neurophysiol. 1996;75:1806-14.

36. Monsivais P, Clark BA, Roth A, Hausser M. Determinants of action potential propagation in cerebellar Purkinje cell axons. J Neurosci. 2005;25:464-72.

37. Hoebeek FE, Khosrovani S, Witter L, De Zeeuw CI. Purkinje cell input to cerebellar nuclei in tottering: ultrastructure and physiology. Cerebellum. 2008;7:547-58.
38. Murphy JT, Sabah NH. Spontaneous firing of cerebellar Purkinje cells in decerebrate and barbiturate anesthesized cats. Brain Res. 1970;17:515-9.

39. Armstrong DM, Rawson JA. Activity patterns of cerebellar cortical neurones and climbing fibre afferents in the awake cat. J Physiol (London). 1979;289:425-48.

40. Kahlon M, Lisberger SG. Changes in the responses of Purkinje cells in the floccular complex of monkeys after motor learning in smooth pursuit eye movements. J Neurophysiol. 2000;84:2954-60.

41. Goossens J, Daniel H, Rancillac A, van der Steen J, Oberdick J, Crepel F, et al. Expression of protein kinase $\mathrm{C}$ inhibitor blocks cerebellar long-term depression without affecting Purkinje cell excitability in alert mice. J Neurosci. 2001;21:5813-23.

42. Loewenstein Y, Mahon S, Chadderton P, Kitamura K, Sompolinsky $\mathrm{H}$, Yarom Y, et al. Bistability of cerebellar Purkinje cells modulated by sensory stimulation. Nat Neurosci. 2005;8:202-11.

43. Shin SL, Rotter S, Aertsen A, De Schutter E. Stochastic description of complex and simple spike firing in cerebellar Purkinje cells. Eur J Neurosci. 2007;25:785-94.

44. Wakamori M, Yamazaki K, Matsunodaira H, Teramoto T, Tanaka I, Niidome T, et al. Single tottering mutations responsible for the neuropathic phenotype of the P-type calcium channel. J Biol Chem. 1998;273:34857-67.

45. Matsushita K, Wakamori M, Rhyu IJ, Arii T, Oda S, Mori Y, et al. Bidirectional alterations in cerebellar synaptic transmission of tottering and rolling $\mathrm{Ca} 2+$ channel mutant mice. J Neurosci. 2002;22:4388-98.

46. Zhou YD, Turner TJ, Dunlap K. Enhanced G protein-dependent modulation of excitatory synaptic transmission in the cerebellum of the $\mathrm{Ca} 2+$ channel-mutant mouse, tottering. J Physiol. 2003;547:497-507.

47. Meier H, MacPike AD. Three syndromes produced by two mutant genes in the mouse. Clinical, pathological, and ultrastructural bases of tottering, leaner, and heterozygous mice. J Hered. 1971;62:297-302.

48. Isaacs KR, Abbott LC. Development of the paramedian lobule of the cerebellum in wild-type and tottering mice. Dev Neurosci. 1992;14:386-93.

49. Rhyu IJ, Abbott LC, Walker DB, Sotelo C. An ultrastructural study of granule cell/Purkinje cell synapses in tottering $(\mathrm{tg} / \mathrm{tg})$, leaner $(\operatorname{tg}(\operatorname{la}) / \operatorname{tg}(1 \mathrm{la}))$ and compound heterozygous tottering/leaner $(\operatorname{tg} / \operatorname{tg}(\mathrm{la}))$ mice. Neuroscience. 1999;90:717-28.

50. Hoebeek FE, Witter L, Ruigrok TJ, De Zeeuw CI. Differential olivo-cerebellar cortical control of rebound activity in the cerebellar nuclei. Proc Natl Acad Sci U S A. 2010;107 (18):8410-5.

51. Borst JG. The low synaptic release probability in vivo. Trends Neurosci. 2010;33:259-66.

52. Fletcher CF, Lutz CM, O'Sullivan TN, Shaughnessy Jr JD, Hawkes R, Frankel WN, et al. Absence epilepsy in tottering mutant mice is associated with calcium channel defects. Cell. 1996;87:607-17.

53. Chung YH, Shin C, Park KH, Cha CI. Immunohistochemical study on the distribution of the voltage-gated calcium channel alpha(1B) subunit in the mature rat brain. Brain Res. 2000;866:274-80.

54. Sawada K, Sakata-Haga H, Ando M, Takeda N, Fukui Y. An increased expression of $\mathrm{Ca}(2+)$ channel alpha(1A) subunit immunoreactivity in deep cerebellar neurons of rolling mouse Nagoya. Neurosci Lett. 2001;316:87-90.

55. Alvina K, Khodakhah K. Selective regulation of spontaneous activity of neurons of the deep cerebellar nuclei by N-type calcium channels in juvenile rats. J Physiol. 2008;586:2523-38.

56. Pedroarena CM. Mechanisms supporting transfer of inhibitory signals into the spike output of spontaneously firing cerebellar nuclear neurons in vitro. Cerebellum. 2010;9:67-76. 
57. Alvina K, Walter JT, Kohn A, Ellis-Davies G, Khodakhah K. Questioning the role of rebound firing in the cerebellum. Nat Neurosci. 2008;11(11):1256-8.

58. De Schutter E, Steuber V. Patterns and pauses in Purkinje cell simple spike trains: experiments, modeling and theory. Neuroscience. 2009;62(3):816-26.

59. Zucker RS. Short-term synaptic plasticity. Annu Rev Neurosci. 1989;12:13-31.

60. Zucker RS. Calcium- and activity-dependent synaptic plasticity. Curr Opin Neurobiol. 1999;9:305-13.

61. Jones MV, Westbrook GL. The impact of receptor desensitization on fast synaptic transmission. Trends Neurosci. 1996;19:96-101.

62. Otis T, Zhang S, Trussell LO. Direct measurement of AMPA receptor desensitization induced by glutamatergic synaptic transmission. J Neurosci. 1996;16:7496-504.

63. Varela JA, Sen K, Gibson J, Fost J, Abbott LF, Nelson SB. A quantitative description of short-term plasticity at excitatory synapses in layer $2 / 3$ of rat primary visual cortex. J Neurosci. 1997; 17:7926-40.
64. Chance FS, Nelson SB, Abbott LF. Synaptic depression and the temporal response characteristics of $\mathrm{V} 1$ cells. J Neurosci. 1998;18:4785-99.

65. Fortune ES, Rose GJ. Short-term synaptic plasticity contributes to the temporal filtering of electrosensory information. J Neurosci. 2000;20:7122-30.

66. Fortune ES, Rose GJ. Short-term synaptic plasticity as a temporal filter. Trends Neurosci. 2001;24:381-5.

67. Abbott LF, Regehr WG. Synaptic computation. Nature. 2004;431:796-803.

68. Tsodyks MV, Markram H. The neural code between neocortical pyramidal neurons depends on neurotransmitter release probability. Proc Natl Acad Sci USA. 1997;94:719-23.

69. Galarreta M, Hestrin S. Frequency-dependent synaptic depression and the balance of excitation and inhibition in the neocortex. Nat Neurosci. 1998;1:587-94.

70. Abbott LF, Varela JA, Sen K, Nelson SB. Synaptic depression and cortical gain control. Science. 1997;275:220-4.

71. Rothman JS, Cathala L, Steuber V, Silver RA. Synaptic depression enables neuronal gain control. Nature. 2009;457:1015-8. 